\title{
The incidence of PAX6 mutation in patients with simple aniridia: an evaluation of mutation detection in 12 cases
}

MRC Human Genetics Unit, Western General Hospital, Crewe Road, Edinburgh EH4 2XU, UK

R Axton

I Hanson

$S$ Danes

G Sellar

$\mathrm{V}$ van Heyningen

J Prosser

Correspondence to: Dr Prosser.

Received 29 August 1996 Revised version accepted for publication 28 October 1996

Richard Axton, Isabel Hanson, Sarah Danes, Grant Sellar, Veronica van Heyningen, Jane Prosser

\begin{abstract}
Twelve aniridia patients, five with a family history and seven presumed to be sporadic, were exhaustively screened in order to test what proportion of people with aniridia, uncomplicated by associated anomalies, carry mutations in the human PAX6 gene. Mutations were detected in $90 \%$ of the cases.

Three mutation detection techniques were used to determine if one method was superior for this gene. The protein truncation test (PTT) was used on RT-PCR products, SSCP on genomic PCR amplifications, and chemical cleavage of mismatch on both RT-PCR and genomic amplifications. For RT-PCR products, only the translated portion of the gene was screened. On genomic products exons 1 to 13 (including $740 \mathrm{bp}$ of the 3 ' untranslated sequence and all intron/exon boundaries) were screened, as was a neuroretina specific enhancer in intron 4.

Ten of the possible 12 mutations in the five familial cases and five of the sporadic patients were found, all of which conformed to a functional outcome of haploinsufficiency. Five were splice site mutations (one in the donor site of intron 4 , two in the donor site of intron 6 , one in each of the acceptor sites of introns 8 and 9) and five were nonsense mutations in exons $8,9,10,11$, and 12. SSCP analysis of individually amplified exons, with which nine of the 10 mutations were seen, was the most useful detection method for PAX6.
\end{abstract}

(F Med Genet 1997;34:279-286)

Keywords: PAX6; aniridia; mutation.

Aniridia is a rare human congenital malformation of the eye characterised by almost complete absence of the iris. There are associated anomalies of cataracts, corneal vascularisation, and glaucoma, so that affected subjects frequently suffer severe visual impairment. About two thirds of cases are familial with autosomal dominant inheritance and a high degree of penetrance, but considerable phenotypic variability. The remainder of cases are sporadic, either isolated aniridia with no malformations outside the eye, or as part of the WAGR syndrome (Wilms' tumour, aniridia, genitourinary abnormalities, and mental retardation). ${ }^{1}$

Pax6 was originally isolated from mouse ${ }^{2}$ and mutations in the gene are responsible for the Small eye phenotypes. ${ }^{3}$ Subsequently, the human PAX6 homologue was shown to be mutated in aniridia patients. ${ }^{4}$ The gene has been studied in a number of organisms, including Drosophila, ${ }^{5}$ showing that its central role in eye development has been conserved throughout the animal kingdom. Evolutionary conservation of the amino acid sequence of the gene is high and between mouse and human there is only a single amino acid difference in the alternatively spliced form. ${ }^{78}$ Despite great differences between insect and vertebrate eyes, mouse Pax6 induces ectopic eye development in transgenic Drosophila. The protein sequence has recognisable functional domains: a 128 amino acid paired domain and a 61 amino acid paired type homeo domain believed to bind to a bipartite DNA recognition sequence, separated by a 78 amino acid linker region, as well as a 152 amino acid proline, serine, and threonine rich C-terminal region (PST) reminiscent of the activation domain of the Oct-2 transcription factor. ${ }^{8} 10$

Mutations have been published for approximately 40 aniridia cases ${ }^{11-14}$ and virtually all lead to premature termination of translation of the protein. Since no differences have been observed between the eye phenotypes associated with deletions of the entire PAX6 gene in WAGR patients and intragenic mutations leading to premature protein truncation in familial and sporadic aniridia patients, PAX6 mutations in aniridia are assumed to be caused by haploinsufficiency or the complete loss of function of one gene copy. ${ }^{1}$ There is one reported example of a missense mutation in aniridia but the result of the mutation may be a non-functional protein. It affects an invariant arginine (R208) which is part of a four amino acid motif immediately 5 ' of the homeo domain of certain pax genes and may provide sequence specific contacts between the domain and the DNA target, ${ }^{15}$ or act as a nuclear localisation signal. ${ }^{12}$

Peters' anomaly, an anterior segment malformation, and aniridia have been proposed as alternative phenotypes resulting from loss of function of the PAX6 locus ${ }^{16}$ based on data which included one patient deleted for PAX6 and affected members of a family with a missense mutation (R26G). The missense 
Table 1 Primers for amplifying the 3' untranslated portion of the gene and the neuroretinal enhancer

\begin{tabular}{|c|c|c|}
\hline \multicolumn{3}{|c|}{ 3' untranslated } \\
\hline K795 & 5'GTTCCCGGAAGTGAACCTGATAT & $309 \mathrm{bp}$ \\
\hline G404 & 5'AAATAATACACCAAAATG & \\
\hline G647 & 5'TAGAGCCGCTTCAGTTCTAC & $254 \mathrm{bp}$ \\
\hline G239 & 5'AGCTTGTTGATCATGGTTTTC & \\
\hline H830 & 5'GATCTGTGTTGGTCATGAAGTTG & $233 \mathrm{bp}$ \\
\hline H831 & 5'ACTTCATCTGTTAACAACCTTTG & \\
\hline H832 & 5'TATGTCAGAAATATCTGTTGGT & $179 \mathrm{bp}$ \\
\hline F948 & 5'CTGAGGATTTCTAGGGAAGAC & \\
\hline G648 & 5'GATAGCTAAAAGGTAGAGTGTG & $208 \mathrm{bp}$ \\
\hline $\mathrm{H} 16$ & 5'GAACAATTAACTTTTGCTGGCC & \\
\hline K796 & 5'TCATACGTTTCTTTTTTGGCCAGC & $247 \mathrm{bp}$ \\
\hline K794 & 5'GGTTAAAAGAAACCTGTGTAATAAAGG & \\
\hline \multicolumn{3}{|c|}{ Neuroretinal enhancer } \\
\hline I132 & 5'ACGGAAAGGGTCGTTTTATC & $185 \mathrm{bp}$ \\
\hline I174 & 5'CTGCACGTCAAGTTTGAGCT & \\
\hline
\end{tabular}

mutation involves another invariant arginine believed to be crucial for DNA binding. A further missense mutation was recently identified in a case of isolated foveal hypoplasia in yet another invariant arginine (R125C) conserved in all identified PAX family members and involved in contact of the paired domain with the DNA target. $^{17}$ Foveal hypoplasia is a common feature of recognised ocular disorders such as albinism and aniridia, but isolated foveal hypoplasia is rare and sporadic. The variable phenotypes resulting from these missense mutations at invariant and functionally crucial arginines may be because of the effects of haploinsufficiency on different genetic backgrounds rather than mutation specific differences. The high degree of genetic conservation in PAX6 would indicate that most mutations are deleterious and that missense mutations which result in altered function rather than loss of function must be associated with a phenotype quite distinct from aniridia.

Congenital cataracts and autosomal dominant keratitis are phenotypes which may be caused by altered or reduced activity of mutant PAX6 rather than no activity. Two members of one family with bilateral cataracts and decreased visual acuity but apparently normal iris development carried a stop mutation at amino acid 353 in exon 12. The resultant protein, prematurely terminated in the activation domain, was shown to have reduced activity rather than no activity. ${ }^{18}$ In another family, two members carried a PAX6 splice mutation which was shown to alter the ratios of the different splice forms. They, too, suffered from bilateral juvenile cataracts with reduced vision, but had intact irides. ${ }^{19}$ Autosomal dominant keratitis has clinical manifestations which overlap with aniridia but iris involvement that is less

Table 2 Primers for RT-PCR (numbering according to Ton et al ${ }^{10}$ )

\begin{tabular}{ll}
\hline C139 & 5'AGAGTGGACAGACATCCGAGA (nt 285-305) \\
I252 & 5'GGATCCTAATACGACTCACTATAGGAACAGACCACCATGCAGAA \\
& CAGTCACAGCGG (nt 363-382 for the last 20 nts) \\
I253 & 5'AGAACTGAAGCGGCTCTAAC (3' untranslated) \\
I254 & 5'CTGAATAACACAATATTCC (3' untranslated) \\
I673 & 5'GGATCCTAATACGACTCACTATAGGAACAGACCACCATGATCGG \\
& TGGTAGTAAACCGAG (nt 615-634) \\
I672 & 5'GGATCCTAATACGACTCACTATAGGAACAGACCACCATGCGACT \\
& TCAGCTGAAGC (nt 1008-1026) \\
B510 & 5'TTTACTACCACCGATTGCCCTG (nt 587-566) \\
B958 & 5'TGTCCAACGGATGTGTGAGT (nt 505-524) \\
B508 & 5'CCTCCTTCCTGTTGCTGGCA (nt 910-891) \\
B509 & 5'TGCCAGCAACAGGAAGGAGG (nt 891-910) \\
D840 & 5'CGCTGTAGGTGTTTGTGAGG (nt 1344-1325) \\
\hline
\end{tabular}

severe. In a family with 15 affected subjects of varying severity, an intron 11 splice acceptor mutation was found. While the exact molecular effect of the mutation was not determined, it probably led to excision of exon 12 and a protein prematurely terminated in the activation domain. ${ }^{20} \mathrm{~A}$ mutant protein truncated in this region had some residual transcriptional activity. ${ }^{18}$

Haploinsufficiency of the PAX6 protein is most frequently achieved by premature termination of translation, either through nonsense mutations, frameshifts, or splicing errors, although a mutation leading to the in frame excision of a major part of the homeo domain of the protein has also been reported, ${ }^{15}$ as well as certain missense mutations, detailed above, which may produce proteins unable to bind their target DNA sequence. Several functional domains of the protein, including the DNA binding homeo and paired domains, the transcriptional activator region in the C-terminus of the protein, and a highly conserved four amino acids $\mathrm{N}$-terminal to the homeo domain, appear to be equally important functionally since mutation in any one of the domains is apparently equivalent in effect. ${ }^{1}$ This argues for a simple or single function for PAX6 which involves DNA binding and transcriptional activation. It is not known what proportion of aniridia patients contain mutations in PAX6 although the gene is now believed to be the major, and probably the only, predisposing locus. ${ }^{21}$ This study aims to test exhaustively for mutations in the gene in a selected group of patients.

\section{Materials and methods \\ MATERIALS}

Established lymphoblastoid cell lines were available for all patients and were used to prepare both RNA and DNA. ${ }^{15}$ Sequence numbering follows Ton et al. ${ }^{10}$

PCR AMPLIFICATION

Genomic PCR

Exons 1-13 were individually amplified for SSCP using oligonucleotides published by Glaser et $a l .^{8}$ The $3^{\prime}$ untranslated region was amplified in six overlapping PCR fragments using oligonucleotides from table $1 ; 185 \mathrm{bp}$ of intron 4 incorporating a neuroretinal enhancer $^{22}$ (table 1) was also screened. Standard PCR conditions were used with a "hot start" of five minutes at $94^{\circ} \mathrm{C}$ before addition of Taq polymerase. For genomic HOT analysis exons 3-13 were amplified singly (exons $5,7,8$, 11) or doubly (exons 3 and 4, 5a and 6,9 and 10,12 and 13) using the same primers and conditions.

\section{$R T-P C R$}

RT-PCR ${ }^{23}$ was carried out with nested primers (table 2) on $1 \mu \mathrm{g}$ of RNA prepared from patient lymphoblastoid cell lines. External primers were $\mathrm{C} 139$ to I253 and three products were produced from internal primer pairs: I252I254 (1357 bp) which includes all the translated sequence; I673-I254 (1104 bp) which initiates in exon 6,84 amino acids short of the 
full length protein; and I672-I254 (711 bp) which initiates in exon 8,215 amino acids short of the full length protein. Additional primers listed in table 1 were used to amplify selected regions of the transcripts when testing for splicing abnormalities in the RNA.

\section{MUTATION DETECTION}

SSCP

PCR products showing a single band of the correct size were used for SSCP screening. ${ }^{24}$ Approximately $10 \mu \mathrm{l}$ of product (depending on DNA concentration) was mixed with $5 \mu \mathrm{l}$ of denaturing dye (95\% formamide $/ 20 \mathrm{mmol} / \mathrm{l}$ EDTA), denatured, and run on $15 \%$ acrylamide gels (29/1 with bis). All samples were run on $18 \mathrm{~cm} \times 16 \mathrm{~cm} \times 1.0 \mathrm{~mm}$ vertical gels for 15 hours at $12^{\circ} \mathrm{C}$ (water cooled) and constant current ( 1 milliamp per $10 \mathrm{bp}$ ). The gels were silver stained as described by Budowle et al. ${ }^{25}$

\section{PTT}

Protein truncation test (PTT) was carried out according to Roest et $a l^{6}$ using the TNT-T7 coupled reticulocyte system (Promega). ${ }^{35} \mathrm{~S}$ methionine labelled protein products were resolved on 8,10 , and $14 \%$ SDS PAGE gels on a Hoefer "Mighty Small" (SE245) electrophoresis apparatus run at 150 volts until the bromphenol blue reached the base of the gel. A non-radioactive rainbow size marker (Amersham 14 300-200 000) was used. Gels were fixed, dried, and autoradiographed.

\section{HOT}

HOT analysis was done according to Condie et $a .^{27}$

\section{Sequencing}

PCR products were purified from LMagarose by Geneclean TM or Wizard PCR Prep. Sequencing was done according to Condie et $a .^{27}$

\section{Restriction site alteration}

Restriction sites were altered by the following mutations. In MATJO a BstNI site is destroyed; in HORLA an MbolI site is destroyed; in VAKIN an MseI site is created; in GAWES a $T s p 45$ I site is created; and in JOPOT a HaeIII site is destroyed. In order to verify the double point mutation found in $\mathrm{p} 236113$, an amplification which creates two BssHII sites in the mutant but only one in the normal allele was set up. The forward primer (J774 from nt 314340 ) introduced two changes ( $C$ for $A$ at nt 324 and $G$ for $C$ at $n t 327$ ) so that the primer sequence 5' CCCATATTCGCGCGCCGTGGAATCC creates a BssHII site in both mutant and normal alleles, as shown. The reverse primer (J775 in intron 4) introduced a $G$ for A change in the penultimate nucleotide, and reads 5' GAAGTCCCAGAAAGACCAGAGGCGC, finishing at +5 of intron 4 . In the mutant, the AAGC change together with the introduced change in J775 creates a second $B s$ HII site, not present in the normal allele. Amplification of the $87 \mathrm{bp}$ fragment followed by digestion with $B s s \mathrm{HII}$ gives a $77 \mathrm{bp}$ fragment in the normal allele and a $77 \mathrm{bp}$ plus a $51 \mathrm{bp}$ fragment in the mutant allele.

\section{Results}

The exact mutations in each of the patients are listed in table 3.

Table 3 Mutation detection in 12 aniridia patients

\begin{tabular}{|c|c|c|c|c|}
\hline Patient & Mutation & Effect & Inheritance & FISH analysis \\
\hline $\begin{array}{l}\text { MATJO } \\
\text { male }\end{array}$ & $\begin{array}{l}\mathrm{G} \rightarrow \mathrm{C} \\
\text { intron } 9 \text { at }-1\end{array}$ & $?$ & Sporadic & No deletion \\
\hline $\begin{array}{l}\text { HORLA } \\
\text { male }\end{array}$ & $\begin{array}{l}\mathrm{A} \rightarrow \mathrm{T}, \mathrm{nt} 1161 \\
\text { exon } 10\end{array}$ & $\mathrm{R} 267 \mathrm{X}$ & Sporadic & No deletion \\
\hline $\begin{array}{l}\text { JAMAD } \\
\text { male }\end{array}$ & $\begin{array}{l}\text { GT del, nt } 1071 / 2 \\
\text { codon } 237, \text { exon } 9\end{array}$ & $\begin{array}{l}\text { Stop } 12 \text { codons } \\
\text { later }\end{array}$ & Sporadic & No deletion \\
\hline $\begin{array}{l}\text { VAKIN } \\
\text { female }\end{array}$ & $\begin{array}{l}T \text { insertion } \\
\text { intron } 6,+2\end{array}$ & $\begin{array}{l}\text { Uses altern splice } \\
\text { Deletes } 36 \text { aa, ex } 6\end{array}$ & $\begin{array}{l}\text { Sporadic } \\
\text { (+talipes) }\end{array}$ & No deletion \\
\hline $\begin{array}{l}\text { OLGIR } \\
\text { female }\end{array}$ & Not detected & - & Sporadic & No deletion \\
\hline $\begin{array}{l}\text { CUICKLE } \\
?\end{array}$ & Not detected & - & Sporadic & ND \\
\hline $\begin{array}{l}\text { MAJMA } \\
\text { female }\end{array}$ & $\begin{array}{l}\text { G del, nt } 1452 \\
\text { codon } 364 \text {, exon } 12\end{array}$ & Stop, immediate & Familial & ND \\
\hline $\begin{array}{l}\text { GAWES } \\
\text { male }\end{array}$ & $\begin{array}{l}C \rightarrow T, n t 969 \\
\text { exon } 8\end{array}$ & R203X & Familial & ND \\
\hline $\begin{array}{l}\text { MEJOH } \\
\text { female }\end{array}$ & $\begin{array}{l}A \rightarrow C \\
\text { intron } 8 \text { at }-2\end{array}$ & $?$ & Sporadic & No deletion \\
\hline $\begin{array}{l}\text { p236113 } \\
\text { female }\end{array}$ & $\begin{array}{l}\text { dbl mut, } \mathrm{AA} \rightarrow \mathrm{GC} \\
\text { intron } 4 \text { at }+3,+4\end{array}$ & Excludes exon 4 & Familial & ND \\
\hline $\begin{array}{l}\text { JOPOT } \\
\text { female }\end{array}$ & $\begin{array}{l}\mathrm{C} \rightarrow \mathrm{T}, \mathrm{nt} 1311 \\
\text { exon } 11\end{array}$ & $\mathrm{R} 317 \mathrm{X}$ & Familial & ND \\
\hline $\begin{array}{l}\text { ANALL } \\
\text { male }\end{array}$ & $\begin{array}{l}\mathrm{G} \rightarrow \mathrm{A}, \\
\text { intron } 6 \text { at }+1\end{array}$ & $\begin{array}{l}\text { Uses altern splice } \\
\text { Deletes } 36 \text { aa, ex } 6\end{array}$ & Familial & $\mathrm{ND}$ \\
\hline
\end{tabular}

$\mathrm{nt}=$ nucleotide, del=deletion, altern=alternate, ex=exon, aa=amino acid, $\mathrm{ND}=$ not done, ?=effect unknown. 
RNA

Three RT-PCR products were amplified from each sample with a view to carrying out PTT analysis. The longest product (I252-I254, see methods) included the alternatively spliced exon 5a which, on amplification, would lead to a $42 \mathrm{bp}$ difference in size in the $1.4 \mathrm{~kb}$ products, not distinguishable on the $2 \%$ agarose gel used to purify the RT-PCR products. In practice, two PCR products were seen, one about $150 \mathrm{bp}$ smaller than expected and presumed to be the result of mispriming. The $5^{\prime}$ end of the PAX6 gene is GC rich and suitable priming sites for PCR amplification of the translated 5 ' portion of the gene frequently terminate with nucleotide runs repeated elsewhere in the region. In order to avoid the complication of alternative splicing and because no ideal priming sequence at the start of PAX6 translation was available, a PCR product was amplified from exon 6 (I673-I254). In order to identify proteins deleted for only a small number of amino acids in the carboxy end of the protein, a product starting in exon 8 was amplified (I672-I254). None of the PCR amplifications of PAX6 from lymphoblastoid cell line RNA was ideal.

Two mutations in these patients could be detected solely on the basis of RT-PCR (VAKIN and ANALL) using primers I673/ I254 (fig 1A). These mutations were not visible using I252/I254 because weak amplification of the mutant product was masked by amplification owing to mispriming. The two patients each contain mutations at the donor site of intron 6 ( $t$ insertion at +2 in VAKIN, $g \rightarrow a$ change at +1 in ANALL) and amplification of the region using primers B958/B508 for a shorter product shows the expected wild type size and one $108 \mathrm{nt}$ shorter in both patients (fig 1B). Hanson et $a l^{15}$ reported a subject with a mutation identical to that of ANALL and showed that an alternative splice site within exon 6 (the GT of nts 612 and 613) was used in preference to the defective site, removing $108 \mathrm{nts}$ of RNA from nt 612 to 719 . It is interesting that the mutant products in VAKIN and ANALL were considerably under-represented in comparison to the wild type even though the mutant RNA contains an in frame deletion rather than a premature stop codon. Clearly, however, a shortened RNA is produced.

Two further patients, MATJO and MEJOH, contain splicing mutations at the acceptor site of introns $(\mathrm{g} \rightarrow \mathrm{c}$ at -1 of intron 9 and $\mathrm{a} \rightarrow \mathrm{c}$ at -2 of intron 8 , respectively) but no abnormally sized RT-PCR products were identified in any of the three routine amplifications, nor by using primers B509/D840 to look for differences in a short product encompassing exons 9 and 10 (fig 1C). It is more difficult to predict the effect of $3^{\prime}$ splice site alterations since the splicing outcome of such mutations is frequently not reported and, where it is reported, the outcome can be exon skipping, use of cryptic site(s), or no detectable aberrant RNA. ${ }^{28}$

One patient ( $\mathrm{p} 236113)$ contained a 5' splice site mutation in intron 4 leading to the excision of exon 4 from the transcript (fig 1D). The excision was seen on second round amplification using primers C139/B510, but would not be visible in any of the products from the amplifications routinely carried out. The mutation itself is, unusually, a double point mutation and, following sequencing, was validated by mutation specific PCR amplification which generated a restriction site (Methods).

Finally, five patients contained point mutations producing nonsense codons (HORLA, JAMAD, MAJMA, GAWES, and JOPOT) and only normal sized RNA would be expected. No mutations were found in two patients (OLGIR and CUICKLE).

\section{PTT (PROTEIN TRUNCATION TEST)}

Because virtually all identified PAX6 mutations result in premature termination of translation of the protein product, ${ }^{1}$ PTT should be an ideal method for identification of mutations in this gene. PTT uses PCR amplification of genomic DNA (where exons are large) or RNA, via RT-PCR, and in both cases it incorporates in one primer a $\mathrm{T} 7$ polymerase promoter and an in frame eukaroytic translation initiation site. In vitro transcription and translation of the resulting PCR product
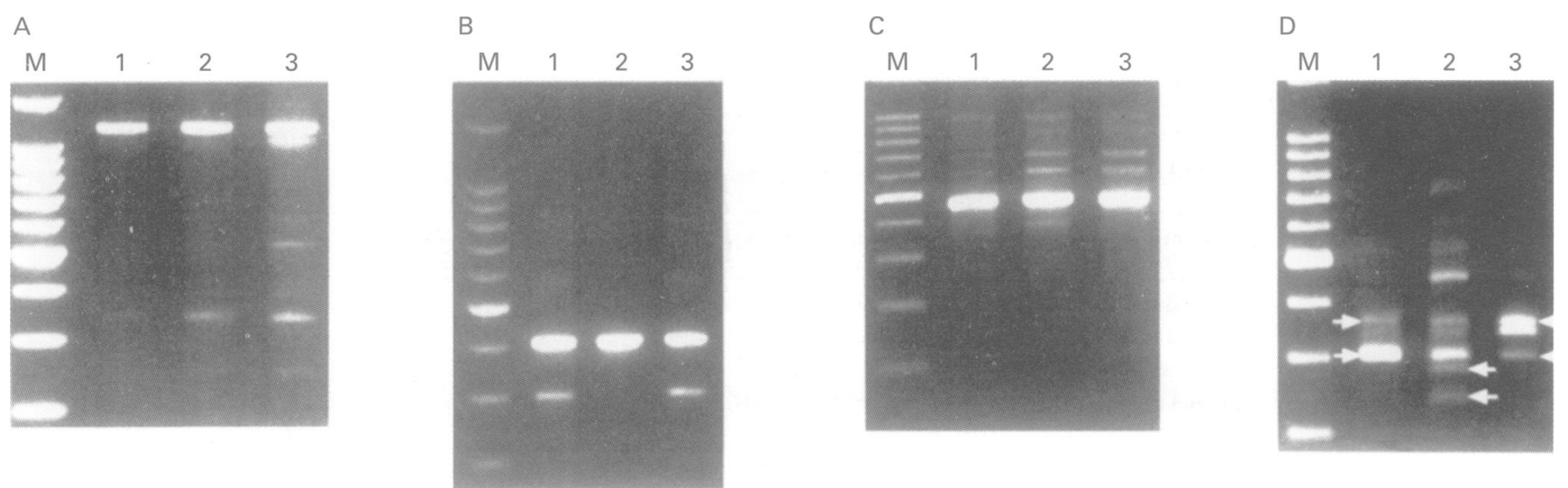

Figure 1 RT-PCR results. In each gel, the unspecified lanes represent wild type results and $M$ refers to the marker, a 100 bp ladder. (A) Primers I672/I254. A full length product of $1104 \mathrm{bp}$ is seen in lanes $1-3$ as well as a shortened product of $996 \mathrm{bp}$ in lane 3 (ANALL). (B) Primers B958/B508. $A$ full length product of $406 \mathrm{bp}$ is present in each lane as well as an under-represented mutant band of 298 bp in lane 1 (ANALL) and lane 3 (VAKIN). (C) Primers B509/D840. A full length product of $453 \mathrm{bp}$ is present in each lane. No shortened products are seen because of excision of exon 10 in lane 1 (MATҰO) or of exon 9 in lane $3(\mathrm{MEFOH})$. (D) Primers C139/B510. The full length sizes of $345 \mathrm{bp}$ ( + exon 5 a) and $303 \mathrm{bp}$ (-exon 5 a) are arrowed in lanes 1 and 3. In lane 2 ( 236113 ) arrowed bands of 284 bp and 242 bp agree with excision of exon 4 from both + and $-5 a$ products. Other bands may be the result of mispriming or missplicing. 


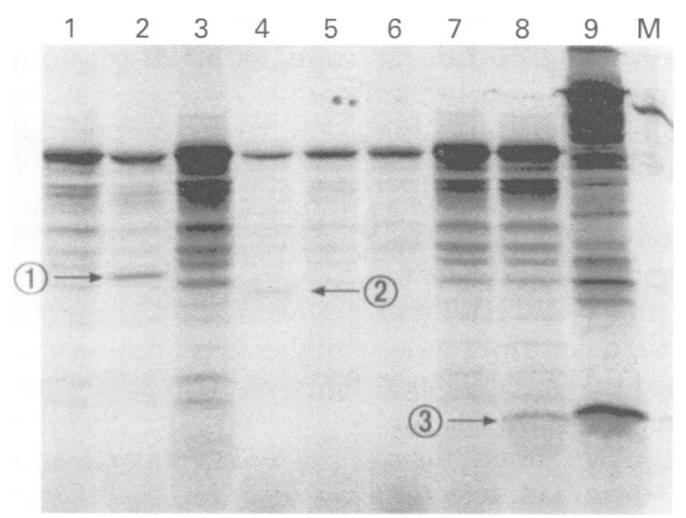

Figure 2 PTT for transcript $1673 / 1254$ run on $14 \%$ SDS $P A G E$ gel. The lanes are loaded MATFO, HORLA, FATO

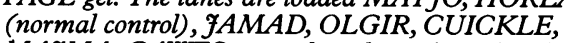

$M A F M A, G A W E S$, control, and non-isotopic rainbow marker (lanes $1-10$ respectively). Numbers 1,2 , and 3 refer to mutant protein bands of $27.5,26.3$, and $17.7 \mathrm{kDa}$, visible above the background.

followed by SDS-PAGE analysis shows the wild type protein product and any truncated protein fragments from mutant RNAs. Size estimation of the truncated protein indicates the position of the putative nonsense codon caused either by point mutation at the site, or by an insertion, deletion, or out of frame splicing mutation $5^{\prime}$ of the stop codon. Direct sequencing identifies the precise mutation. Mutations in three patients were identified in this way.

For PTT on PAX6 we translated three different PCR products in vitro, one incorporating sequence from the ATG which initiates protein synthesis to 40 nucleotides downstream of the termination TAA, one starting in mid exon 6, and one starting in mid exon 8, and the products were run on three densities of acrylamide gel. Proteins differing in size by less than $2 \mathrm{kDa}$ (the -exon 5 a product) would not be apparent when analysing the $60 \mathrm{kDa}$ full size protein product.

Truncated proteins indicating mutations in three patients were observed in samples HORLA, JAMAD, and GAWES (fig 2). These truncated proteins, as well as a spurious truncation product (JOPOT), were observed in the I673-I254 products. No mutations were identified on the basis of translation of the full length RT-PCR product, nor by translating the shortest product. Six truncated proteins, which might theoretically have been observed, were not (VAKIN, ANALL, MATJO, MEJOH, MAJMA, and JOPOT). In view of the fact that the abnormally spliced RNA for four of these patients was either noticeably underrepresented (VAKIN and ANALL) or not seen (MATJO and MEJOH), inability to see the protein products is not surprising. One mutation was inaccessible to the PTT test (p236113) since no mutant RNA would be amplified. Of the 10 mutations found, three were observed with the PTT test. This is at best a $30 \%$ detection rate, at worst $25 \%$. Furthermore, the test was most informative on a template which does not include the initial 70 amino acids of the protein.

PTT itself carries a background of shorter and much less intense protein bands, ${ }^{29}$ some- times attributed to translation from internal methionines in the RNA transcript. Also, it is well known that mRNAs carrying in frame stop codons are under-represented in the cell ${ }^{30}$ and when mutant RNA is under-represented the truncated protein translated from it will also be under-represented. The overall effect of underrepresented translation products viewed on a background of non-specific truncated proteins, together with an inability adequately to control mispriming in the PCR amplification used for the test, means that PTT is less than ideal as a detection system on breakthrough RNA transcripts from lymphoblastoid cell lines of PAX6 patients.

SSCP

All exons of PAX6 in all the patients were screened genomically with individual exons

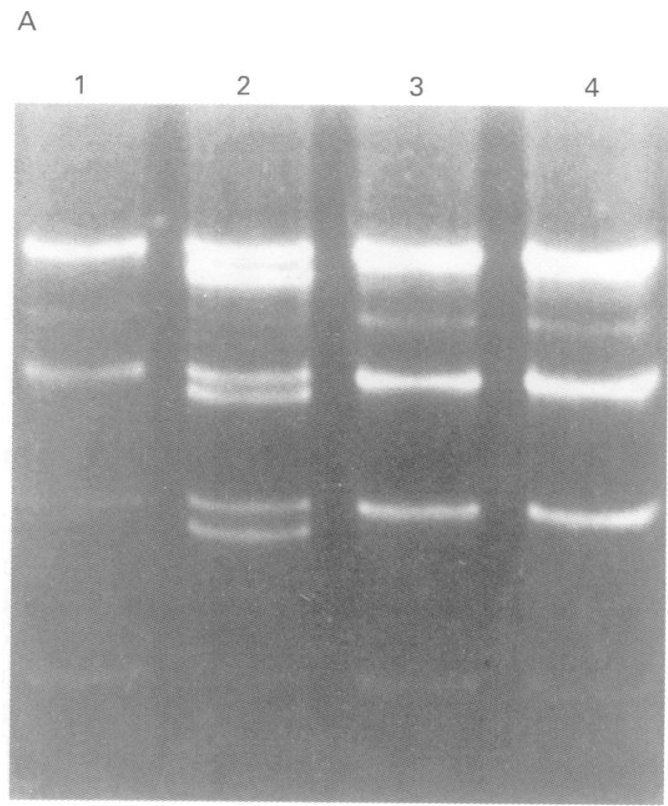

B

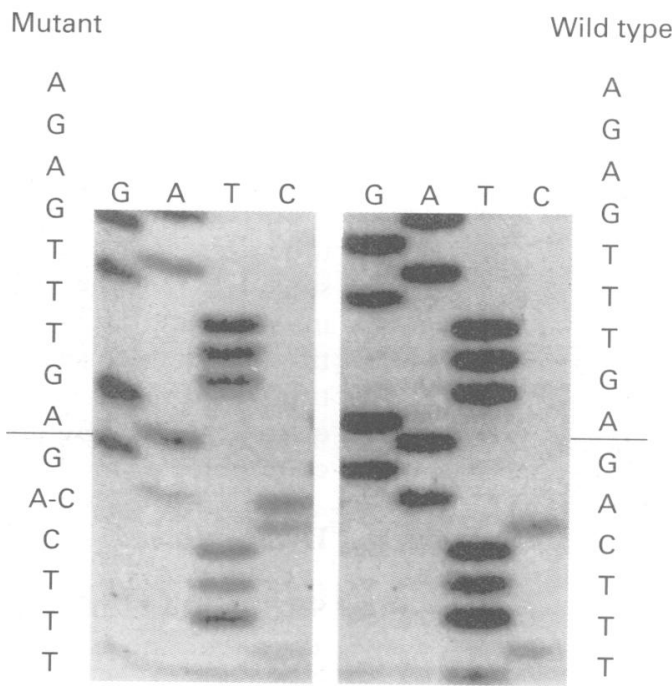

Figure 3 (A) Silver stained SSCP bands for exon 9 on a non-denaturing $15 \%$ acrylamide gel. Lanes $1-4$ are loaded $M A F M A, M E F O H$ (mutant), HORLA, and 236113 . (B) Sequence change in MEFOH. Horizontal line marks intron/exon boundary. 
amplified in fragments ranging in size from 154 to $370 \mathrm{bp}$. When only the coding portion of exon 13 is considered, all fragments except one (exon 8 at $370 \mathrm{bp}$ ) are under $300 \mathrm{bp}$ in size. Fig 3 illustrates a mutant band in exon 9 of $\mathrm{MEJOH}$ and verification by DNA sequencing. Nine of the 10 detected mutations were observed in this way (either a $75 \%$ detection rate if it is assumed that OLGIR and CUICKLE have as yet undetected mutations or a $90 \%$ rate if it is assumed that after exhaustive screening by three methods OLGIR and CUICKLE do not contain PAX6 mutations in the regions screened). A $75 \%$ rate of detection is good and $90 \%$ would be excellent for a single set of SSCP conditions. Additionally, SSCP is the easiest mutation detection method available. Two polymorphisms were detected in intron $9(\mathrm{C} \rightarrow \mathrm{T}$ at -12 and $\mathrm{A} \rightarrow \mathrm{T}$ at -13 , data not shown). A further $740 \mathrm{bp}$ of $3^{\prime}$ untranslated sequence in exon 13, much of which is evolutionarily highly conserved, ${ }^{8}$ was screened in equivalent sized fragments as well as $185 \mathrm{bp}$ of intron 4 believed to contain a PAX6 neuroretinal enhancer. ${ }^{22}$ No polymorphisms were found.

HOT

PAX6 was screened at the genomic level (exons 3 to the translated portion of exon 13) and the RNA level (the intermediate I673-I242 fragment missing the initial 70 amino acids) (fig 4). Although at the genomic level one previously unidentified mutation (VAKIN) was found, it is evident that carrying out eight HOT analyses for each of 12 DNA samples to find one mutation more than could be detected by SSCP is not an efficient use of resources. HOT on RT-PCR products, while theoretically attractive, was practically disappointing, probably for a number of reasons. If RNA transcripts which are misspliced or contain in frame stop codons are severely under-represented they are unavailable for analysis. HOT on RT-PCR products excised from gels precludes analysis of splicing variants, which result in products different in size from the wild type, yet because of the misprimed or misspliced products analysis of non-gel purified samples is not an option. For HOT analysis to approach $100 \%$ efficiency of detection, both templates must be used reciprocally as probes. Before labelling the probe DNA, it is an absolute requirement that it be excised and cleaned from gels. In conclusion, HOT at the genomic level is too labour intensive and HOT at the RNA level not practically suitable, since mutant and wild type transcripts are unequally represented, frequently of different sizes, and occasionally contain misprimed products.

\section{Discussion}

TECHNIQUES

SSCP analysis of individually amplified exons, by which nine of the 10 mutations (nine mutations in 12 patients) were identifiable, was the easiest and most efficient detection method for PAX6. Because of under-representation of mutant transcripts as well as amplification of misprimed and misspliced products, we found

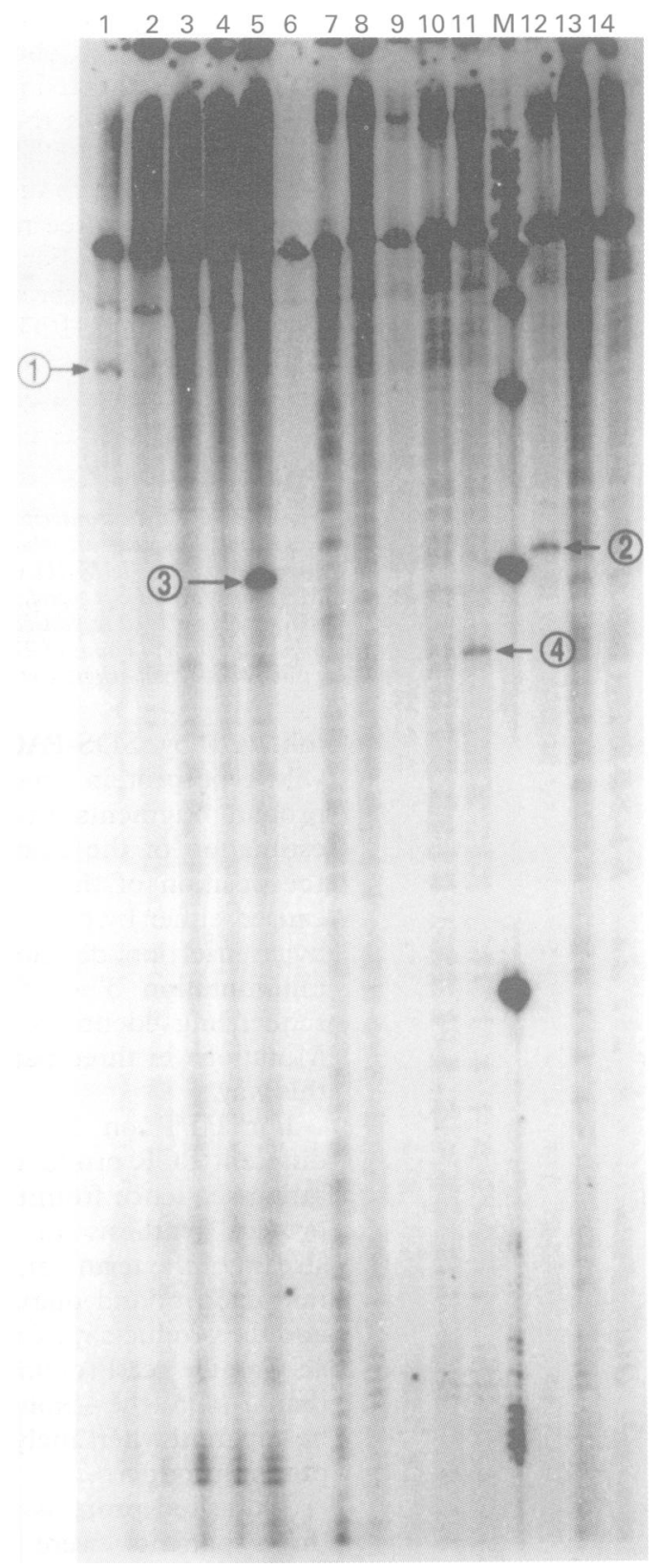

Figure 4 HOT analysis of the genomic exon 9 and 10 fragment (550 bp) in which lanes 1-7 are hydroxlyamine modified, lanes 8-14 osmium tetroxide modified, and lane $M$ is a $100 \mathrm{bp}$ marker. The samples are loaded in the following order: FOPOT, SIMO (normal), CUICKLE, HORLA, MATҰO, OLGIR, DEMI (normal). The arrowed changes are the result of the following changes: (1) FOPOT polymorphism $C \rightarrow T$ at -12 of intron 9; (2) $M A T 7 O$ polymorphism $A \rightarrow T$ at -13 of intron 9; (3) $M A T 7 O$ mutation $G \rightarrow C$ at -1 of intron 9 ; (4) HORLA mutation $A \rightarrow T$ at 1161 in exon 10.

that RT-PCR on breakthrough transcripts in this gene was not consistently useful. Interestingly, Aoufouchi et $a l^{31}$ discuss depletion of mRNA harbouring in frame nonsense mutations which is independent of protein synthesis, effected at the level of splicing, tissue specific but not species specific, and only loosely overlaps with tissue specific transcription. They also found that nonsense mutations resulted in defective splicing. Certainly much remains to be discovered of the effect of premature nonsense mutations on transcript abundance and splicing products. Our experience of breakthrough transcripts of the PAX6 gene in LCLs is that they are unreliable for mutation 
detection. Although PTT would be the theoretical method of choice for a gene in which virtually all detected mutations lead to premature truncation of the protein, we found that because of the unreliability of representation of the RT-PCR products, only three of 10 mutations, or three mutations in 12 patients, were identified. For similar reasons, HOT analysis of breakthrough transcripts was not useful. By using HOT analysis at the genomic level, one mutation not seen with SSCP was identified, but in a gene with 13 short exons this detection route is not practical for screening purposes.

Clearly, for an exhaustive mutation analysis of the PAX6 gene one would choose a DNA based method. Of the techniques tried by us, SSCP was most useful and could be used as a primary screen with genomic HOT as a secondary method for negative cases. However, for concerted analysis at the DNA level and a detection rate approaching $100 \%$, DGGE or CDGE should be considered. ${ }^{27}$ This is a DNA based screening techniques with a greater efficiency of detection than SSCP but no more difficult to execute, although it requires a certain effort of input to establish. Before embarking on this study, PTT was the obvious method of choice for mutation detection; retrospectively, however, DGGE might have been a better investment.

\section{MUTATIONS}

Ten of the possible 12 mutations in the five familial and five sporadic patients were found so that PAX6 mutations were found in $90 \%$ of the aniridia cases (table 3 ). Of the two patients in whom no mutations were seen, patient OLGIR was thought by the submitting laboratory to be cytogenetically abnormal. However, FISH analysis using a cosmid covering the whole of the PAX6 gene and other cosmids proximal to it showed no rearrangements. Distal markers were not assessed. CUICKLE was received as a transformed cell line from a sporadic aniridia case without further details. It is certainly possible that there are undetected PAX6 mutations in these two patients, either in the regions screened by us, or in regions not screened, including introns and further untranslated regions, but there is no reason to suspect a mechanism which does not involve PAX6. There are many different ways of causing loss of function, not all of which can be easily screened. For instance, mutations outside the exonic regions can lead to loss of expression from one allele. Such mutations may be found deep within introns or in $5^{\prime}$ or $3^{\prime}$ control elements whose role in PAX6 is suggested by the occurrence of patients with $3^{\prime}$ chromosomal rearrangements leading to position effects. ${ }^{21}$ Promoter mutations have been described for a number of genes, but the promoter elements of PAX6 are not yet defined. Searching for such long range mutations is currently not feasible.

Five mutations involved splicing errors: two coded for protein products missing 36 amino acids in the paired domain, one led to absence of exon 4 and therefore absence of the initiating
ATG, and two had unknown effects on the translated protein but could be presumed to interrupt the protein from exon 9 or 10 onwards, deleting most of the activation domain. Although two splicing mutations were in frame and did not result in a premature stop codon, both the RNA and protein resulting from the event would be shorter. The predicted mutant proteins would be deleted for a helix-turn-helix motif of the paired domain and, as Hanson et al ${ }^{15}$ pointed out for an identical mutation, it is difficult to imagine that the deletion would not have a deleterious effect on the function of the paired domain. Five mutations created premature stop codons in exons $8,9,10,11$, or 12 . Three removed or interrupted the homeo domain (exons 8,9 , and 10) and two prematurely terminated the protein after the homeo domain affecting the PST transcriptional activation region (exons 11 and 12). The stop codon in exon 12 (MAJMA) would delete the terminal 58 amino acids of the PST domain and is one of the most C-terminal protein truncations detected in PAX6. The patient, however, was identified in a classical aniridia family and did not manifest a noticeably mild phenotype. As far as is possible to determine from the information given, ${ }^{12}$ a mutation at +2 of exon 13 , which very likely would delete the terminal 28 amino acids of the PST domain, was found in a patient with aniridia. Clearly, interruption late in the transcriptional activation domain of the protein can be as deleterious as total absence of the copy, but it is worth noting that truncations of PAX6 just $\mathrm{N}$-terminal to MAJMA's mutation in the PST domain were responsible for the milder phenotypes of congenital cataracts ${ }^{18}$ and autosomal dominant keratitis. ${ }^{19}$ Genetic modifiers play a major role in the final determination of a phenotype and there are now well documented examples, particularly in mouse, of mutant alleles giving rise to different phenotypes on different genetic backgrounds. ${ }^{32}$ The segregation of modifier genes that interact with PAX6 would explain phenotypic heterogeneity of mutations which are identical or nearly identical. Non-functional mutant proteins are the presumed outcome of the 10 gene alterations found in this screen and conform to previous data indicating that aniridia is caused by haploinsufficiency of PAX6 protein.

We wish to thank the clinicians and scientists who provided patient samples: Drs N Dennis, G Fekete, B Fleck, K MacDermot, M Mannens, C A Oley, C I Phillips, H H Punnett, A mot, M Mannens, C A Oley, C I Phillips, H H Punnett, A
Wilkie, and D Zaletayev. Dr Alison Brown and Anne Seawright Wilkie, and D Zaletayev. Dr Alison Brown
prepared the DNA and RNA samples.

1 Hanson I, van Heyningen V. PAX6: more than meets the eye. Trends Genet 1995;11:268-72.

2 Walther C, Guenet JL, Simon D, et al. Pax: a murine multigene family of paired-box-containing genes. Genomics 1991;11:424-34

3 Hill RE, Favor J, Hogan BLM, et al. Mouse Small eye results from mutations in a paired-like homeo-containing gene. Nature 1991;354:522-5.

4 Jordan T, Hanson I, Zaletayev D, et al. The human PAX6 gene is mutated in two patients with aniridia. Nat Genet 1992;1:328-32.

5 Quiring R, Walldorf U, Kloter U, Gehring WJ. Homology of the eyeless gene of Drosophila to the Small eye gene in mice and aniridia in humans. Science 1994;265:785-9. 
6 Loosli F, Kmita-Cunisse M, Gehring WJ. Isolation of a Pax-6 homolog from the ribbonworm Lineus sanguineus. Pax-6 homolog from the ribbonworm $L$.
Proc Nat Acad Sci USA 1996;93:2658-63.

7 Walther $C$. Walther C, Gruss P. Pax-6, a murine paired box gene is expressed in the developing CNS. Development 1991;113:

8 Glaser T, Walton DS, Maas RL. Genomic structure, evolutionary conservation and aniridia mutations in the human PAX6 gene. Nat Genet 1992;2:232-9.

9 Halder G, Callaerts P, Gehring WJ. Induction of ectopic eyes by targeted expression of the eyeless gene in Drosophila. Science 1995;267:1788-92.

10 Ton CCT, Hirvonen $\mathrm{H}$, Miwa $\mathrm{H}$, et al. Positional cloning and characterization of a paired box- and homeoboxcontaining gene from the aniridia region. Cell 1991;67: 1059-74.

11 Martha A, Ferrell RE, Mintz-Hittner H, Lyons LA, Saunders GF. Paired box mutations in familial and sporadic aniridia predicts truncated aniridia proteins. $A m \mathcal{F}$ Hum Genet 1994;54:801-11.

12 Glaser T, Walton DS, Cai J, Epstein JA, Jepeal L, Maas RL. PAX6 gene mutations in aniridia. In: Molecular genetics of ocular disease. New York: Wiley-Liss, 1995:51-82

13 Sahly I, Abitbol M, Ghazi I, et al. Identification of a new mutation causing aniridia in the PST domain of PAX6. Vision Res 1995;35:2137.

14 Zhu D, Li Y, Traboulis EI, Levin AV, Hussels IEM. PAX6 gene mutations in aniridia. Am $\mathcal{F}$ Hum Genet 1995;57:1350. 5 Hanson IM, Seawright A, Hardman K, et al. PAX6 mutations in aniridia. Hum Mol Genet 1993;2:915-20.

16 Hanson IM, Fletcher JM, Jordan T, et al. Mutations at the $P A X 6$ locus are found in heterogeneous anterior segment malformations including Peter's anomaly. Nat Genet 1994; 6:168-73.

17 Azuma N, Nishina S, Yanagisawa H, Okuyama T, Yamada M. PAX6 missense mutation in isolated foveal hypoplasia. M. PAX6 missense mutation
Nat Genet 1996;13:141-2.

18 Glaser T, Jepeal L, Edwards JG, Young SR, Favor J, Maas RL. PAX6 gene dosage effect in a family with congenital cataracts, aniridia, anophthalmia and central nervous system defects. Nat Genet 1994;7:463-71.

19 Epstein JA, Glaser T, Cai J, Jepeal L, Walton DS, Maas RL. Two independent and interactive DNA-binding subdomains of the $P A X 6$ paired domain are regulated by alternative splicing. Genes Dev 1994;8:2022-34.

20 Mirzayens F, Pearce WG, MacDonald IM, Walter MA. Mutations of the $P A X 6$ gene in patients with autosomal dominant keratitis. Am F Hum Genet 1995;57:539-48.
21 Fantes J, Redeker B, Breen M, et al. Aniridia-associated cytogenetic rearrangements suggest that a position effect may cause the mutant phenotype. Hum Mol Genet 1995;3: 415-22.

22 Plaza S, Dozier C, Langlois MC, Saule S. Identification and characterization of a neuroretina-specific enhancer element in the quail Pax-6 (Pax QNR) gene. Mol Cell Biol 1995;15: 892-902.

23 Kawasaki ES. Amplification of RNA. In: PCR protocols: a guide to methods and applications. New York: Academic Press, 1990:21-7.

24 Orita $M$, Iwahana $H$, Kanazawa $H$, Hayashi $K$, Sekiya $T$ Detection of polymorphisms of human DNA by gel electrophoresis as single-strand conformation polymorphisms. Proc Natl Acad Sci USA 1989;86:2766-70.

25 Budowle B, Chakraborty R, Giusti AM, Eisenberg AJ, Allen RC. Analysis of the VNTR locus DIS 80 by the PCR followed by high-resolution PAGE. Am f Hum Genet 1991; 48:137-44.

26 Roest PAM, Roberts RG, Sugino S, van Ommen GJB, den Dunnen JT. Protein truncation test (PTT) for rapid detection of translation-terminating mutations. Hum Mol Genet 1993;2:1719-21.

27 Condie A, Eeles R, Borresen AL, Coles C, Cooper C, Prosser J. Detection of point mutations in the p53 gene: comparison of single-strand conformation polymorphism constant denaturant gel electrophoresis, and hydroxy lamine and osmium tetroxide techniques. Hum Mutat 1993;2:58-66

28 Krawczak M, Reiss J, Cooper DN. The mutational spectrum of single base-pair substitutions in mRNA splice junctions of human genes: causes and consequences. Hum Genet 1992;90:41-54

29 Plummer SJ, Anton-Culver H, Webster L, et al. Detection of BRCA 1 mutations by the protein truncation test. Hum Mol Genet 1995;4:1989-91.

30 Maquat LE. When cells stop making sense: effects of Maquat LE. When cells stop making sense: effects of
nonsense codons on RNA metabolism in vertebrate cells. nonsense codons on

31 Aoufouchi S, Yelamos J, Milstein C. Nonsense mutation inhibit RNA splicing in a cell-free system: recognition of mutant codon is independent of protein synthesis. Cell 1996;85:415-22.

32 Dietrich WF, Lander ES, Smith JS, et al. Genetic identification of Mom-1, a major modifier locus affecting Mininduced intestinal neoplasia in the mouse. Cell 1993:75: $631-9$ 